\title{
THE MOVEMENT FOR IMPROVED FINANCING AND ACCOUNTING PRACTICE IN TORONTO
}

\author{
By Horace L. Brittain,
}

Director, Toronto Bureau of Municipal Research.

The city of Toronto has increased in population from 238,642 in 1905 to 470,144 in 1914 , or over 97 per cent. During the same period its assessed valuation increased from $\$ 149,159,206$ to $\$ 509$,366,151 , or over 240 per cent, and the city taxes from $\$ 2,834,025$ to $\$ 9,865,068$, or over 248 per cent. During the last five years the necessities of a rapidly growing city have raised general taxation per capita from $\$ 14.71$ to $\$ 24.84$, or over 68 per cent, and special taxation per capita from $\$ 2.32$ to $\$ 2.96$, or over 27 per cent.

The rapid growth of the city demanded rapid extensions of public works and services, which in turn greatly increased the problems of city financing and municipal accounting and reporting. It is not strange on the one hand that the city's accounting and budgetary system should have been more or less outgrown during the last two decades or, on the other hand, that a popular movement looking toward better methods of fact-producing, of fact-reporting and of financing should have sprung up and gained considerable force under the unpleasant stimulus of the increasing financial burden of government.

In 1913, largely through the energy of one public-spirited citizen a committee of over one hundred citizens was formed to study improved municipal methods. This committee, known as the Civic Survey Committee, raised among its members a sum of $\$ 6,000$ to pay for a first-hand study of administration at the City Hall. Having obtained the consent of the Mayor and City Council, a contract was made with the New York Bureau of Municipal Research for a report on five important city departments, viz.: The City Treasurer's Department, the Department of Works, the Fire Department, the Assessment Department and the Property Department. It is the first of these that particularly concerns us in this article as the City Treasurer is not only the chief financial officer of the city but pays the city's bills, receives directly or indirectly all the city's revenues 
and is the chief accounting officer of the city, subject, with other city department heads, to the accounting control of the City Auditor.

The report of the Civic Survey Committee, prepared by the New York Bureau of Municipal Research, found much to commend in the accounting and financial system of the city. It states:

In contrast to many American cities, the books of the department were found to be neatly and clearly kept and balanced with periodical regularity. . . . . . In the main the accounting technique employed in the Treasurer's office is superior to that in most cities where surveys have been made. . . . . . The records and accounts maintained in the arrears of taxes division are exceedingly well kept. They are balanced and proven periodically with the general ledger and it is possible at all times to ascertain the status of each individual item. As at present administered the office of the City Auditor (an independent official not in the Treasury Department) has many commendable features. The periodical regularity of its inspection of revenue-producing offices, its reconciliation and audit of current and arrears of taxes accounts, and the detailed audit of the Treasurer's general cash accounts are especially commended. The salutary effect of an independent audit of outside departmental accounts from time to time must of necessity be good.

As the report was intended primarily, however, to point out places where improvements could and should be made, time and money were not wasted in listing in detail the many good points of the system. The report concerns itself chiefly with constructive criticisms and recommendations concerning:

1. The administration of the city's finances;

2. The methods of accounting and reporting used by the city-methods which should make available at all times to administrative officers, members of council and citizens information about the city's financial conditions and the results of financial transactions.

\section{Defects in the Administration of the City's Finances}

Legal Obstructions Requiring Legislation. The revenue year does not correspond with the fiscal year. The fiscal year is the calendar year, but tax payments are made in July, September and November. This necessitates the payment of large sums in interest as the requirements of the city during the first six months cannot be met out of miscellaneous revenue.

The penalty for delay in paying taxes is inadequate and in fact encourages prolonged delay As a flat rate of 5 per cent only is charged on unpaid taxes no matter how long they may have been 
in arrears, and as tax-rolls have in the past been held open for five or six years taxpayers have, in effect, been able to borrow from the city at rates varying between $5 / 6$ per cent per annum and 5 per cent. As the city at present has to pay from 5 per cent to 6 per cent for loans, this involves a heavy penalty in interest. In this connection it is worthy of note that the reforms recently introduced into the tax collection division in one year and a quarter have closed up all tax-rolls for 1909, 1910, 1911 and 1912, so that at present no arrears of taxes are on the books save those for 1913 and 1914 . In future tax-rolls will be closed "at the end of the year succeeding the year in which they become due" 1 -a step in advance which will save tens of thousands of dollars to the taxpayers annually. ${ }^{2}$

The water revenue collection period does not correspond with the fiscal year. Water rates are payable semi-annually in advance on April 1 and October 1. If payments were made on January 1 and July 1 large sums of money would be available to the city much earlier in the fiscal year.

Lack of Effective Control Over the City's Finances. The Board of Control which is elected annually is supposed to be the city's administrative body. At present the formulation of a financial program is left to the incoming board with the result that the estimates are not passed until April or May and the first installment of taxes cannot be collected before July. This system means that the city has practically to operate without a program for five months in the year, the interest bill of the city is greatly increased, and the electorate is handicapped by having, for the most part, to pass on financial policies after the fact rather than before the fact.

The departmental estimates at present in use are inadequate although very considerable improvements have been effected during the past year. Standard forms for the preparation of departmental estimates are not used giving information with respect to cost and unit costs for each function, and costs for each organization unit, separating current expenses from capital outlay, and showing cost of all objects of expenditure. A few departments do supply such information but the majority have not accounts which could produce the necessary information to supply a basis for such estimates.

'Civic Survey Report, p. 20.

These reforms were due largely to the continued recommendations of the City Auditor in his annual reports. 
There is inadequate publicity in the whole budget-making procedure. Departmental estimates are given no publicity whatever, and the draft estimates, prepared from these, have a very narrow distribution. While deputations may be heard on particular features, there is no regular method provided for the taxpayers' cooperation in budget making.

While the draft estimates are prepared under the direction of the Mayor and Board of Control and submitted to Council in its name, it is hardly submitted as a definite recommendation of the Mayor or the board, although practice is perhaps tending toward this consummation so devoutly to be wished. The Mayor and Council have no opportunity to go before the people on a proposed program but only on a record of accomplishments. Even here, the division of responsibility, the lack of significant details supporting the estimates, and the lapse of time make it difficult to locate or enforce responsibility.

Although a city by-law provides for the establishment of grades in the city's service, as a matter of actual fact a civil list with carefully outlined grades and rates of pay does not exist. This makes it difficult to make intelligible that part of the estimates which deals with personal services.

Discussions of personal service items are apt to degenerate into discussions of the personal or official fitness of particular individuals in the city's employ.

At present the Toronto Council, like dozens of others on the continent, gravely attempts to control expenditure by passing vouchers before payment. This is evidently not only a waste of time, as the Council must act without sufficient knowledge, but it delays the passing of bills to such an extent as to cause the loss of large sums in discounts offered for prompt payment.

Methods Employed in Financing. The almost universal tendency to over-estimate miscellaneous income and under-estimate necessary expenses for the purpose of keeping down the tax rate has not passed by Toronto. The temptation to pass on the resulting deficit to posterity has usually been too strong to resist. It is an encouraging sign of the times that a decided check has been administered to both these practices and that there seems to be a determination to allow no overdrafts this year the excuse for which, in previous years, has 
been an alleged or real under-estimate of necessary expenditure. Overdrafts have always been illegal.

It would be strange, indeed, if Toronto has sidestepped the pitfall of charging to capital account legitimate current expenditures. The outstanding Toronto example of this practice is the custom of issuing debentures to pay for repairs of the track allowance areas of the streets. As the franchise of the Toronto Street Railway expires in 1921, the terms of debentures issued have been decreased a year at a time so that the life of all debentures will expire in that year. This will make the final payments extremely large but will, undoubtedly, lead to the abandonment of the practice now in vogue.

In the past Toronto, in common with most municipalities, has not been at sufficient pains to coördinate the term of the bonds it sold with the life of improvements. The necessary facts were not available for the determination of the actual life of improvements. It is natural therefore that in many cases long term bonds were issued for short-lived improvements. An improvement in this respect is very noticeable and has been facilitated by the reorganization of such departments as Works and Street Cleaning which have developed or are developing modern systems of cost accounting.

Legal and other difficulties make local improvements costly. Contrary to general belief, however, special local improvement rates have not increased as rapidly as general taxation. The situation is best described in the words of the Civic Survey Report:

Because of the present practice of having to wait until the entire cost of local improvement work is ascertained and all disputes are settled, and because the city must borrow the necessary funds to carry on the work, heavy interest charges for bank loans are incurred. Considerable delay in determining final costs is made necessary ty expropriating more property than is ultimately found necessary in street widening operations. For that reason the eity must wait until the surplus property is sold before actual costs are obtainable. Debentures cannot be issued until such costs are determined and the collection of assessments made against the property benefitted is necessarily deferred.

\section{Lack of Adequate Supervision over the Administration of Finances}

In the past it has been the practice to apportion from time to time debenture discounts to the various capital expenditure accounts with the result that very important facts necessary to sound financing were hidden or so obscured as to be of no effect. 
At the time of making the survey the banks allowed 3 per cent on all existing city balances and charged the city $4 \frac{1}{2}$ per cent on all overdrafts up to the amount of city sinking fund deposits in the banks, "which means that the city was paying $1 \frac{1}{2}$ per cent interest for the use of its own money represented by cash in the sinking funds." The relation of this to the time set for paying the first installment of taxes is obvious.

The Treasurer, at the time of the survey, had no means of exercising effective supervisory control over miscellaneous revenue collection. This is the condition in most cities.

As, at the same period, the City Auditor had no means for performing an independent inspection of deliveries, and as he did not have in his possession copies of contracts or specifications, there was insufficient basis for the audit of claims. This condition still exists to some extent.

A year or two ago it was the practice of the City Auditor to sign all checks drawn upon the City Treasury, but recently arrangements have been made with several departments by which payrolls are covered by a single cheque, the individual payments being made by paymasters' cheque or otherwise. Much time, however, is still wasted on unnecessary details, time which the auditor is anxious to use in assisting in various necessary departmental accounts installations.

In 1913, it was customary to invest sinking funds in Toronto city debentures. One sale from the sinking fund at 17 points below par led to a large loss. Both these facts represent undesirable or even dangerous tendencies, especially when, as in Toronto, the sinking funds are not administered by an independent commission, but by the same authorities who have to raise money by the issue of debentures.

\section{Recommendations re the Administration of the City's Finances}

The following is a short statement of the recommendations of the Civic Survey Report with regard to city financing:

1. That the Mayor and Board of Control assume full responsibility for financial proposals to be submitted to the taxpayers just before the election at the beginning of each year. It appears that this method is at present legally impossible, but there is no legal 
obstacle to the preparation of the estimates between October and December of each year so that they can be acted upon by the Council immediately after the first meeting in January. While this compromise would not establish responsible leadership to such an extent it would enable the city to operate under a program for ten months in the year instead of six and would save the city large sums of money in interest.

2. That forms of annual estimates be established which will show comparative expenditure data and estimates. These would set forth "actual as well as estimated expenses and capital outlay for each function or activity performed by each department or other organization unit, as well as overhead cost, including fixed charges." These should be further analyzed so as to show cost or estimated cost in terms of objects of expenditure, that is:

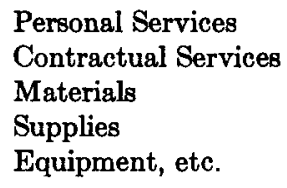

3. That a budget be prepared which would show:

$a$. A comparative balance sheet showing current assets and liabilities and surpluses or deficits;

b. A comparative operation account;

c. A comparative capital account;

d. A consolidated fund statement, showing the condition of the general fund, capital account funds, special and trust funds, sinking funds;

e. A request for appropriations;

$f$. Detailed departmental estimates.

While it has been found impossible to secure all these reforms in budget procedure the draft estimates for this year were a great improvement on any submitted previously. The following quotation from the Annual Report of the Toronto Bureau of Municipal Research gives a clear idea of the present situation:

A completely scientific budget is, of course, impossible before the establishment of accounts which produce the facts upon which a scientific budget can be based. This fact has been persistently drawn to the attention of the city government and receives the heartiest assent of the City Auditor and City Treasurer, as well as other prominent officials of the city. That the City Treasurer and 
the Assistant City Treasurer will work effectively along the right lines in respect to budget reform, is shown conclusively by the draft estimates for 1915 recently submitted to the Board of Control and the Council. For the first time the estimates contain, in addition to a column showing the actual expenditures for the preceding year and the estimates for the current year, a column showing the estimates for the preceding year. This is, therefore, the first budget issued by the city of Toronto which makes intelligent comparison possible.

Another excellent feature of the draft estimates is that expenditures and receipts, not directly affecting taxation, are placed on opposite pages, with corresponding items in corresponding situations on the pages. The previous practice was to place all the expenditures together and after them all the receipts. This made the process of analysis so formidable that the average citizen could not afford the time to make a study of the annual estimates. For the first time also the draft estimates are indexed, by letters and numbers of pages. In fine, the estimates are prepared not only with the end in view of giving information to those most familiar with the facts, but to make the getting of information easier by any citizen who has sufficient interest to study the city's program for the year.

\section{Defects in Methods of Accounting and Reporting Used by the City}

While considerable improvement has been made in the annual financial report of the city of Toronto, the following statements of the Civic Survey Report with regard to the financial statements issued before 1913, in the main, still hold good:

1. The balance sheet, or the most summary picture of financial conditions, is buried in a mass of detail where it is all but lost. The report is not indexed and it is only the man who has the tenacity of purpose and interest to turn through 570 pages who will find the balance sheet at all. ${ }^{3}$

2. In the "condensed statement of receipts and disbursements," there has been an attempt to combine in one form both an operation account (revenues and expenditures) and an account-current (statement of cash receipts and disbursements) with beginning and ending balances.

3. The "abstract of receipts and disbursements" has the same defect as the "summary" that precedes it, with a different classification.

Since this criticism was written the 1913 Treasury Report has been issued which shows the following improvements: The detailed statements of receipts and disbursements have been cut down until they occupy only 72 pages instead of 558 pages as in 1912. The detailed schedule of insurance on property has been condensed so that it now occupies but two pages and forms a valuable summary. The report is also indexed and reference to any statement is thus made comparatively easy. But the accounts are still prepared on a purely cash basis, no particulars of income and expenditure being given unless same was received or paid in cash during the current year and the balance sheet still conveys but little information to the average citizen. 
4. The "detailed statements of receipts and disbursements" are little more than a printed register or lists of individual or detailed transactions of the city for a year.

5. The statement of "current assets and liabilities" is misleading in certain respects and fails to bring out essential financial relations. It does not give a clear picture of conditions about which officers and citizens are called upon to think.

With regard to the city's published balance sheet the Civic Survey Report states that it

cannot be of much assistance in thinking about Toronto's financial and business problems for the reasons that

1. It goes into too much detail for a summary statement-so much so that it does not help one to grasp at a glance significant relations which should be brought to public attention.

2. In so far as it presents a picture of financial conditions, it is confused.

3. There is a commingling of current assets and liabilities with capital assets and liabilities and the resources and obligations of the sinking fund.

4. From the statement presented, it cannot be determined whether there is a current surplus or a deficit, nor even what is the present condition of the cash account.

5. Current cash, capital cash, and trust cash are thrown together without taking into consideration cash reserves.

6. Neither the balance sheet nor the summary of current assets and liabilities is supported in all its items by the details of the report.

7. Questions raised by the balance sheet cannot be answered without special inquiry through the department of finance.

8. The only conclusion to be drawn is that the balance sheet now used is a makeshift and not an integral part of the reporting system.

9. In several instances, estimated figures are used which do not appear on the books of account.

\section{Accounting and Reporting Recommendations}

The defects in the Annual Report, of course, reflect defects in the system of accounting upon which the report is based. In order to remedy these defects the Civic Survey Report recommended as follows:

1. That a new form of annual report be adopted which will more clearly set forth financial conditions and results.

2. That a new general ledger be installed which will contain such accounts and only such as are needed in the preparation of summary statements showing assets and liabilities, revenues and expenditures, surplus and deficit and the condition of the city's funds.

3. That all supporting details of information, which are needed for purposse 
of administration and for furmishing such analysis of summary accounts kept on the general ledger, be carried in detailed records.

4. That the supporting and detailed accounts be so classified that information in any detail or summary desired may be drawn off without re-analysis or duplication of work.

5. That the accounts of the general ledger and the detailed ledgers be independently posted so that the accuracy of statements when taken off the detailed records may be proved by being checked by totals to the general ledger control accounts.

6. That a summary statement of assets and liabilities in balance sheet form, revenue and expense account and statement of the condition of the city's funds be drawn off of the general ledger and published monthly; and that, quarterly, a detailed comparative statement of departmental expenditures be made available to the mayor, council and public press.

7. That the quarterly statements of expenditure be accompanied by comparative operation statistics furnished by departments in such form that units of cost may be shown whenever practicable.

8. That the statistics of expenditures be kept in such analysis as may be needed in the preparation of the annual estimates.

In making its constructive criticisms and recommendations the Civic Survey Report recognized that the heads of city departments were not personally responsible for defects shown. The following paragraphs from the report are significant:

In pointing to some of the obvious defects in methods of reporting of the treasury department, officers of this department are not charged with incompetence or neglect. Toronto officials are in the same situation as are the officials of other fast-growing cities. The current work increases rapidly, the daily routine demands on official attention are such that persons in responsible positions have little time or opportunity left to study the business system as a whole, much less to take the time needed to work out constructive plans and obtain the coopperation essential to a successful installation of new methods and procedures. Each $d$ ay's work must be done or the business will stop. Each day is a full day. The larger the city the more difficult it becomes to make a change (1) by reason of the increasing demands on the responsible officers; (2) by reason of the large number of institutional adjustments which must be brought about to make any change effective. The working out of some systematic method of doing business and the installation of new procedure must necessarily be performed by persons who are relatively free from the grinding details of administration. The only solution is either in a temporary or permanent staff which is not charged with making the decisions essential to direction and control. As a matter of organization, Toronto, like most public corporations, has its full quota of "line" officers and men but is lacking on the "staff" side. So long as matters of this kind are left to men who must keep the wheels of business moving, those in command must find themselves at an increasing disadvantage. Changes may be made, and frequently as a matter of adaptation, but unless the whole subject of 
institutional needs is taken up systematically, change after change in method will be made under circumstances such that while they may be adapted to getting better results, each change may increase the cost and red tape of doing business.

Toronto has been peculiarly fortunate in having had many years of continuous service of the principal officers in its departments. But the best thing that these officers can do for Toronto and for themselves is to focus public attention on the difficulties of the problem before them in order that they may have the support of public opinion in bringing about an adaptation of organization and methods to service requirements.

In the later months of 1914 the two chief accounting officers of the city, namely, the City Auditor and the City Treasurer, together with the head of the chief spending department of the city, namely, the Commissioner of Works, whose department has more accounting to do than any other operating department in the city, were appointed a committee to report on a reformed system of accounting for the city of Toronto. They visited personally several cities and later sent their chief accountants to go carefully into the details of the methods used in Philadelphia and New York City. They spent three weeks in the work. As a result of their study they issued a report to the Mayor and Board of Control making recommendations which if followed would supply practically all the elements necessary for a thoroughly modern accounting system.

At time of writing (June, 1915) definite action has not been taken upon this report by the city authorities but there is every reason to hope that such action will be taken before the time comes for the preparation of the 1916 estimates in the fall. In the meantime the departments concerned are continuing the making of detailed improvements which do not involve a uniform system of accounting for the city. For example: A distribution cash book has been established by the Treasurer's Department in accordance with a recommendation contained in the report above mentioned, while the improvements which have been under way in the Works Department and the City Auditor's Department for some considerable time are progressing rapidly.

If adopted, the plan will make the City Auditor actually, what he is now potentially, the controller or commissioner of accounts, while the City Treasurer will become practically a commissioner of finance. The rearrangement and clear definition of the functions of these two officials on the lines advocated by the report will constitute an immense step in advance. 
As in the past, Toronto will meet her problems courageously. Her officials welcome any hints she can gain from the experience of other cities. This article is written with the hope that the history of Toronto's movement for financing, accounting and reporting reform may be suggestive to other municipalities. 